\title{
Empowerment of Disaster Affected Farmers - A Comprehensive Study on Developing Feasible Strategies for Empowering Thane Affected Cashew Growers in Cuddalore District of Tamil Nadu, India
}

\author{
M. Balarubini1 ${ }^{*}$, C. Karthikeyan ${ }^{2}$ and T.N. Sujeetha ${ }^{1}$ \\ ${ }^{1}$ Department of Agricultural Extension and Rural Sociology, TNAU, Tamil Nadu, India \\ ${ }^{2}$ Agricultural College and Research Institute, TNAU, Coimbatore, Tamil Nadu, India \\ *Corresponding author
}

\begin{tabular}{|c|c|}
\hline & A B S T R A C T \\
\hline & Agriculture and Horticulture are the dominant components in the economy of \\
\hline Keywords & Thane affected States and the Union Territory. Hence, the need of the hour is to \\
\hline $\begin{array}{l}\text { Empowerment, Thane, } \\
\text { Farmer profitability, } \\
\text { community }\end{array}$ & $\begin{array}{l}\text { be more specific, it is seen that cashew is the most important crop of India and } \\
\text { about } 32162.72 \text { ha of cashew area has been damaged due to the occurrence of }\end{array}$ \\
\hline $\begin{array}{l}\text { engagement and } \\
\text { capacity building. }\end{array}$ & Thane in Tamil Nadu (Directorate of Horticulture, Government of Tamil Nadu, \\
\hline Article Info & sample size of 194 Thane affected cashew growers. Study the feasible strategies \\
\hline $\begin{array}{l}\text { Accepted: } \\
\text { 28 September } 2017 \\
\text { Available Online: } \\
10 \text { November } 2017\end{array}$ & $\begin{array}{l}\text { for empowering Thane affected cashew growers. The respondents were } \\
\text { interviewed personally by a well-structured interview schedule. The extension } \\
\text { strategies included in this study will serve as a blue print for empowering Thane } \\
\text { affected cashew farmers for effectively mitigating the impact of the disaster. }\end{array}$ \\
\hline
\end{tabular}

\section{Introduction}

\section{Strategies for empowering Thane affected} cashew growers

Empowerment refers to increasing the economic, political, social, educational or spiritual strength of an entity or entities. The word empowerment may literally sound big in terms of its meaning associated with larger objectives but, it is the micro level impact that the process of empowerment creates to a society of target is of greater significance. Empowerment in general is linked to deprived segment of people with respect to poverty, social inequalities, economic instability and livelihood insecurity. Most of the above mentioned factors are prevalent in any developing society, whereas there anomalies and disasters that create livelihood insecurity and poverty. Thane storm is one such natural disaster that has unimaginably affected and flipped the lives and livelihoods of thousands of people who are dependent on agriculture, fisheries etc., in the Cuddalore District of Tamil Nadu.

Strategy is a Greek word Stratēgia meaning "art of troop leader; office of general, command, general ship". Strategy is important 
because the resources available to achieve these goals are usually limited. Strategy generally involves setting goals, determining actions to achieve the goals, and mobilizing resources to execute the actions. The special package implemented under cyclone Thane rehabilitation programme in Tamil Nadu (Krishnamoorthy, 2014). The 'Providing assistance for the II year maintenance of perennial crops in Cyclone Thane affected areas', 'encouraging pandal cultivation of vegetables', 'establishment of district horticulture extension cum training center', 'modernization of state horticulture farms' (Directorate of Horticulture and Plantation Crops, 2012).The government should take the steps to erect the walls for preventing from the flood prone area and sea level rise. The deltaic regions are highly experienced the agricultural loss, hence the government should announce to removal of agricultural loans (Punithavathi et al., 2012). The Immediate strategies proposed for adoption of Thane affected people are as follows: (i) involve women led disaster task force as volunteers to oversee relief and rehabilitation. Afforestation involving women's groups in planting and maintenance, (i) organize health camps to address problems by women, children and aged, (ii) distribute relief according to needs assessment by women's groups, (iii) address drinking water issues. The one year mitigation strategies proposed for adoption of Thane affected people are as follows: (i) form/strengthen disaster task force in all coastal villages to reduce the risk, (ii) Provide livelihood support for the affected community. The couple of year's mitigation strategies proposed for adoption of Thane affected people are as follows: (i) build permanent houses for all vulnerable communities (Women Federation, 2012).Tsunami rehabilitation in Agriculture are: (i) participatory needs assessment for rehabilitation is required and the parameters of assessment of damage need to scientific, (ii) variation in damages and intensity in different places/soils call for differing rehabilitation techniques, (iii) technical expertise to be converged, (iv) farmers working on the land to be taken for rehabilitation rather than ownership of land(Tamil Nadu Tsunami Resource Centre (TNTRC), 2006). The Agriculture rehabilitation should focus on: (i) simple farming systems process to sustain productivity of soil and crop, (ii) integration of Horticulture, Forestry and Animal Husbandry in the consecutive year and (iii) capacity building and interventions on disaster preparedness (Chandramohan, 2006).

This part of the study aims at drawing relevant strategies and implementable action plans to empower the Thane affected cashew growers. It was intentionally decided not to provide any strategies or action plans that enhances only the adoption of technologies recommended by the Government Departments. Instead a comprehensive strategy that envisages overall empowerment of affected growers is being proposed. Understanding the practical importance of this study, the strategies envisaged is two dimensional i.e. strategies for Short Term and Long Term empowerment goals (Fig.1).

\section{Materials and Methods}

Considering the criteria viz., maximum area under cashew cultivation as well as maximum number of farmers affected by Thane storm, Panruti block of Cuddalore district was selected for the study. Considering the same criteria, the Block Development Office was also consulted to select the top three villages' viz., Vegakollai, Kadampuliyar and Marangur which had maximum area under cashew cultivation as well as maximum number of farmers affected by Thane storm. Employing proportionate sampling method, 194 Thane affected cashew growers were selected 
randomly from the three selected villages. The primary data was collected during November, 2014.Based on the survey experience of the researcher and the interaction with stakeholders of Thane relief management officials, suitable strategies were formulated for empowering Thane affected cashew growers.

\section{Short term empowerment strategies}

Immediate measures to mitigate the impact and adverse aftermath of Thane storm over the cashew growers in Panruti taluk of Cuddalore District can be categorised under the Short Term Empowerment Strategies and the elements are mentioned \& explained:

\section{Farmer profitability}

Profitability in business terms is the ability of a business to earn a profit. A profit is what is left of the revenue a business generates after it pays all expenses directly related to the generation of the revenue, such as producing a product, and other expenses related to the conduct of the business' activities.

The same definition holds good for a farmer because farming is as good as an enterprise or business that involves even higher degree of risk than any other investment friendly businesses. Continuity of any income generating activity primarily depends on the consistency of the activity in delivering profits. Hence for a farmer to continue farming as an income generating enterprise, profitability is a crucial factor. The major victim of any natural or man-made disaster is agriculture and people who are dependent on it for their livelihood (Fig. 2).

The strategy of enhancing Farmer profitability as a short term empowerment for Thane affected cashew growers can be achieved by 3 major levers namely; (a) Productivity enhancement, (b) Production cost optimization and (c) Ancillary income generation sources. Any control or modifications on the price level to enhance farmer profitability will not provide a practically feasible solution as it is driven by market conditions or demand and supply. Detailed action plans to enhance farmer profitability through the above mentioned levers is discussed in detail.

\section{Productivity enhancement}

Farm productivity is directly linked to the inherent potential of the soil, other production related natural resources and most importantly adoption of Good Agricultural Practices (GAP) as suggested by various agencies working on the implementation of GAPs with the farming community. Through the discussions in the previous chapters, it was understood that the productivity level of cashew in the Thane affected Farms has reduced drastically due to deterioration of soil, water and most importantly physical damage to the well grown yielding cashew trees. In the same background, State Department of Agriculture and Horticulture have proposed various production technology related recommendations as immediate measures to enhance farm productivity like adoption of VRI-3 seedlings, treatment of the seedlings with bio-fertilizers, appropriate spacing and regular pruning. More than any other production practices, adoption of high yielding varieties like VRI-3 can have significant impact on crop productivity. There is a quantifiable proportion $(38.66 \%)$ of respondents reported non-adoption of VRI-3 grafts. The major reason quoted by them were longevity of the variety and lack of its availability in required numbers for nonadoption. Hence it is proposed to have a localized large scale VRI-3 graft producing sub research stations to meet the requirements of the farmers in the affected region vicinity. 
Other Good Practices like bio-fertilizer treatment of seedlings, appropriate spacing and pruning shall be sensitized to farmers through continuous engagements with the affected farming community through village level meetings and result demonstration etc.,

\section{Production cost optimization}

If productivity enhancement is one leg of farmer profitability which is still a slow walker, the immediate effect on increased farmer profitability can be achieved through minimizing the Cost of production.

Cost optimization or minimization can be achieved through reduced cost on inputs or resources, elimination of non-value adding or less-value adding activities.

In this regard, some of the initiatives recommended by the State Department of Agriculture and Horticulture are provided below along with their non-adoption status and suggestions to enhance adoption of the same;

\section{Ancillary income generation opportunities}

Investments into multiple portfolios are a universally preferred option for investors as they seek security of their investment, in case an option fails the other investment would save. The similar scenario is thought to provide livelihood security to farmers, by facilitating them to have ancillary sources of income other than cashew. Farmer having more than one source of income is extremely critical for disaster prone zones as their livelihood is at stake post every single disaster. In this regard, State Department of Agriculture has provided Black Gram T9 seeds at 100 per cent subsidy through Public Distribution System for intercropping purpose. This initiative has witnessed an outstanding adoption level of Cent per cent, thanks to the direct benefits demonstrated by the crop during the absence of cashew and the mechanism through which distribution of Black Gram T9 seeds were distributed.

This strategy can also be utilised for some more commercial, single season growing crop as an additional source of income other than cashew.

State Department of Agriculture can also take up Animal Husbandry Services in the region of Thane affected cashew Growers in terms of free door step Artificial Insemination Services to enhance cattle population for both dairy and drought purposes.

Farmers can be trained and provided with basic kit resources to start small scale income generation activities like Mushroom Cultivation, Vegetable cultivation etc.,

\section{Farmer support}

Short Term Empowerment strategies can never be complete without having plans to support the farmers with other than crop support. The farmer support in this context is anticipated to empower the Thane affected cashew Growers in moving into prosperity from the claws of poverty. Farmer Support should be provided in terms of Weather Resilient Crop Protection Technologies and Structured Community Engagement. The detailed action plans suggested under the strategic element of farmer support.

\section{Weather resilient crop production technologies}

The strategic action points depicted in the figure above under Farmer Support strategic lever is aimed at addressing some of the environmental and social constraints reported by the respondents. 


\section{Action Plan suggestions for Productivity Enhancement}

\begin{tabular}{|c|c|c|}
\hline Production Technology & Non-Adoption \% & Major Reasons \\
\hline VRI-3 Grafts & 38.66 & $\begin{array}{l}\text { Lesser life span of VRI-3 when compared with } \\
\text { conventional varieties } \\
\text { Less confidence on resilience capacity of VRI-3 to } \\
\text { weather vagaries as against conventional varieties } \\
\text { Adoption is impeded by non-availability of adequate } \\
\text { saplings from the RRS (Regional Research Station) } \\
\text { Vridhachalam. }\end{array}$ \\
\hline \multicolumn{3}{|c|}{$\begin{array}{l}\text { Suggestions for Increased Adoption of VRI-3 Grafts } \\
\text { A localized VRI-3 Grafts production unitsattached to the RRS, Vridhachalam can be established in the } \\
\text { nearby vicinity of the Thane storm high impact cashew growing zone. This will enable the farmers in } \\
\text { having better access and enhanced availability of VRI-3 grafts for adoption. } \\
\text { Exclusive farmer training programmes like exposure field visits to VRI-3 planted yielding farms, } \\
\text { workshops of advantages of growing VRI-3 can be made constantly to encourage level of adoption and } \\
\text { effective crop calibration. }\end{array}$} \\
\hline
\end{tabular}

\section{Production Cost Optimization}

\begin{tabular}{|c|c|c|}
\hline & & \\
\hline Bio-C & 71.65 & $\begin{array}{l}\text { edge } \\
\text { y of bio-control agents } \\
\text { ontrol agents during } \\
\text { urce. }\end{array}$ \\
\hline \multicolumn{3}{|c|}{$\begin{array}{l}\text { Suggestions for Increased Adoption of Bio-control Agents } \\
\text { Since Bio-control Agents aims at cost effective and sustainable management of cashew crop related pests } \\
\text { and diseases, increased adoption of the same is expected to bring down the cost spent on crop protection } \\
\text { by the farmers. } \\
\text { Continuous engagement through Village level meetings, training programmes and result demonstrations } \\
\text { on the use and benefits of bio-control agents can be done at regular intervals. } \\
\text { Tie-up with local NGOs, policy bodies like Panchayats to position and distribute bio-control agents can } \\
\text { be taken up by the State Department of Agriculture and Horticulture. }\end{array}$} \\
\hline & & \\
\hline (110 & 8 & $\begin{array}{l}\text { it of } \\
\text { rmer } \\
\text { tting }\end{array}$ \\
\hline \multicolumn{3}{|r|}{$\begin{array}{l}\text { gation \& Fertigation } \\
\text { echnology can reduce significant labour costs through } \\
\text { tion process. } \\
\text { ter to irrigate the crop thereby saving the notional cost } \\
\text { ertigation among Thane affected cashew growers, the } \\
\text { ightly moderate the modalities of subsidy and support } \\
\text { d to benefit based on income level and impact level } \\
\text { eficiary pattern is skewed more towards big farmers. }\end{array}$} \\
\hline
\end{tabular}




\section{Action Plan suggestions for Farmer Support}

\begin{tabular}{|l|l|l|}
\hline Farmer Support & Reported \% & Major Reasons \\
\hline Unpredictable Weather & 73.20 & Lack of knowledge and support on taking up Weather \\
Resilient Crop Production.
\end{tabular}

\section{Community Engagement}

\begin{tabular}{|c|c|c|}
\hline & $1 \%$ & ajor Reas \\
\hline & 28.35 & $\begin{array}{l}\text { Lack of single point of credible contact to seek } \\
\text { recommendations. }\end{array}$ \\
\hline \multicolumn{3}{|c|}{$\begin{array}{l}\text { Suggestions with regard to Community Engagement } \\
\text { 'Village Level Disaster Management Committees' can be established in alignment to the social fabric of the } \\
\text { Village. These committees can take up the responsibility of liaising with various agencies in obtaining the most } \\
\text { relevant Disaster Management practices and in turn will communicate the same to the other members of the } \\
\text { Village. These committees shall be framed with a common objective at Panchayat level comprising various } \\
\text { members of the community. }\end{array}$} \\
\hline
\end{tabular}

\section{Benefits Distribution}

\begin{tabular}{|l|l|l|}
\hline Benefits Distribution & $\begin{array}{l}\text { Reported } \\
\text { \% }\end{array}$ & Major Reasons \\
\hline $\begin{array}{l}\text { Diversion of relief fund received for some other } \\
\text { purposes }\end{array}$ & 29.38 & $\begin{array}{l}\text { Lack of rigorous monitoring mechanism } \\
\text { resulting improper fund utilization. }\end{array}$ \\
\hline $\begin{array}{l}\text { Non-availability of relief material in required } \\
\text { quantity }\end{array}$ & 81.96 & Inadequate planning and distribution pattern. \\
\hline Non-availability of relief material in right time & 71.65 & $\begin{array}{l}\text { Inadequate or improper assessment of credit } \\
\text { needs. }\end{array}$ \\
\cline { 1 - 2 } Inadequate Credit for buying inputs & 72.68 & $\begin{array}{l}\text { Lack of planning as financial status not } \\
\text { considered instead of land area. }\end{array}$ \\
\hline Subsidy provision based on area owned & 58.25 & $\begin{array}{l}\mid \\
\text { Suggestions with regard to Benefits Distribution } \\
\text { 'Provision of Benefits based on Income Levels' is a potential solution to the improper allocation of benefits as } \\
\text { the level of farmer income is directly proportionate to the extent of damages or losses incurred by the farmer due } \\
\text { to the disaster. Hence the farmers as well as the study suggests to take up provision of benefits considering the } \\
\text { farmers financial status rather than land owned. The criteria of land are will lead to skewed distribution of } \\
\text { benefits only to big farmers rather than supporting the farmers who are in need. Provision of benefits shall be } \\
\text { strongly backed up by detailed planning. } \\
\text { 'Real Time Monitoring Mechanism' can be developed by leveraging the presence of the Village Level Disaster } \\
\text { Management Committee. The Government agencies executing the provision of benefits can tie up with these } \\
\text { committees to monitor and report the progress, status and deviations from planned levels of benefits distribution. }\end{array}$ \\
\hline
\end{tabular}




\section{Zone Specific Disaster Prediction and Alert System}

\begin{tabular}{|l|l|l|}
\hline Crisis Preparedness & Reported \% & Major Reasons \\
\hline $\begin{array}{l}\text { Fear about another Natural } \\
\text { Disaster }\end{array}$ & 75.26 & $\begin{array}{l}\text { No prevention measures available to face the natural } \\
\text { disaster. }\end{array}$ \\
\hline Lack of interest in farming & 56.19 & $\begin{array}{l}\text { Unprecedented weather and subsequent natural disasters } \\
\text { resulting in losses. }\end{array}$ \\
\hline $\begin{array}{l}\text { Suggestions in regard to Crisis Preparedness } \\
\text { 'Zone Specific Disaster Prediction Systems' is an ambitious suggestion that emerges out of this research. } \\
\text { Customized prediction of disasters, their intensity and probable impact will enable any community/developmental } \\
\text { agency to devise and execute appropriate preparations to counter the anticipated impact of the storm. State Department } \\
\text { of Agriculture/Horticulture shall liaise with IMD (Indian Meteorological Department) to set required infrastructure and } \\
\text { resources to develop micro zone specific disaster predictions and their relevant management plans. This will enable the } \\
\text { communities in effectively managing the natural disasters and sustain their interest in farming. }\end{array}$ \\
\hline
\end{tabular}

\section{Disaster Risk Mitigation Structures}

\begin{tabular}{|l|l|l|}
\hline Crisis Preparedness & Reported \% & Major Reasons \\
\hline Lower Self Esteem & 75.26 & $\begin{array}{l}\text { Fear of shelter and facilities to sustain livelihood in the } \\
\text { event of disasters }\end{array}$ \\
\hline Lack of Conviction & 56.19 & $\begin{array}{l}\text { Poor infrastructural facilities to meet the food, health and } \\
\text { sanitation needs of people. }\end{array}$ \\
\hline $\begin{array}{l}\text { Suggestions in regard to Crisis Preparedness } \\
\text { 'Disaster Risk Mitigation Structures' are engineered infrastructures that empowers communities in mitigating } \\
\text { the risks posed by any natural disasters. Government agencies can lock hands together in developing these } \\
\text { structures. Ministry of Agriculture can liaise with Food Corporation of India in building weather resilient } \\
\text { warehouses to store adequate quantity of food requirements in the disaster prone zones. Public Works Department } \\
\text { shall establish surface and sub-surface drainage systems to dispose flooded water in case of heavy downpour. The } \\
\text { local Government body shall work on constructing sprawling Community Shelters with adequate make-shift } \\
\text { sanitation facilities. }\end{array}$ \\
\hline
\end{tabular}

\section{Training and Development}

\begin{tabular}{|l|l|l|}
\hline Capacity Building & Reported \% & Major Reasons \\
\hline $\begin{array}{l}\text { Lack of Technical } \\
\text { Guidance }\end{array}$ & 75.26 & $\begin{array}{l}\text { Fear of shelter and facilities to sustain livelihood } \\
\text { in the event of disasters }\end{array}$ \\
\hline $\begin{array}{l}\text { Lack of motivation from } \\
\text { development agencies }\end{array}$ & 56.19 & $\begin{array}{l}\text { Development agencies not empowered with } \\
\text { comprehensive crisis preparedness plans. }\end{array}$ \\
\hline Suggesta
\end{tabular}

\section{Suggestions in regard to Capacity Building}

'Training and Development' is a powerful process and an important tool in any organizational or social environment for empowerment of the Human Resources. Irrespective of technologies, interventions and strategies deployed for disaster management; it is the people who will play the pivotal role in mitigating the impact of natural disasters in long term. Hence the following Training \& Development programmes can be taken up by various Government agencies for the Thane affected cashew growers are recommended.

Training programmes on (i) Disaster resilient crop production technologies, (ii) productivity enhancement related technologies, (iii) cost optimization during cultivation, (iv) first aid techniques during health hazards, (v) SOS contact procedures and awareness on roles of various agencies during disasters etc., 


\section{Natural Resource Augmentation}

\begin{tabular}{|c|c|c|}
\hline & & \\
\hline & & \\
\hline \multicolumn{3}{|r|}{$\begin{array}{l}\text { Impact on climate change, the micro climate of } \\
\text { tural resources. The following are some of the } \\
\text { e farmers as well as the researcher towards } \\
\text { terms of its physical, chemical and biological } \\
\text { en leaf manuring, application of farm yard } \\
\text { tanks, usage of bio fertilizers, application of } \\
\text { nted by taking up desilting the existing village } \\
\text { actices like trench cum bund, farm percolation }\end{array}$} \\
\hline
\end{tabular}

A significant proportion of Thane affected cashew growers reported on unpredictable weather $(73.20 \%)$ and unfavourable soil conditions due to subsequent storm $(52.58 \%)$ as an important constraint faced by them in regard to mitigation of the impact caused by the disaster. In this regard, weather resilient crop production technologies gain utmost importance to safeguard the crop and farmers from the hands of catastrophic natural disasters like Thane.

State Department of Agriculture/Horticulture can liaise with NGOs, farming community and other local social engagements in implementing the above mentioned suggestions in large scale to reap the benefits of Disaster Resilient Crop Production Systems. A detailed study can be taken up in future to ascertain the modalities of engagement with respect to execution of the above mentioned initiatives.

\section{Community engagement}

During the study, an elite group of respondents reported that having multiple sources providing various recommendations for a similar problem (28.35\%) as a constraint impeding their decision making process in adopting the apt interventions for mitigation of impact created by Thane Storm. Community engagement is identified to be a strategic element that can bring in commonality among understanding and minimize information fidelity.

\section{Benefits distribution}

Disaster management and mitigation inherently will have provision of various benefits in terms of financial, material and resources to the affected population. In the context of Thane affected cashew growers, it was evident from the above mentioned discussions on availing various benefits like drip irrigation, erection of bore wells etc., shown minimal adoption primarily due to lack of access to these benefits. This is primarily due to the fact that the benefits are provided based on land area owned by the farmer and not his extent of disaster impact. To ensure proper distribution of benefits and utilization of the same, a rigorous mechanism to monitor the benefits distribution process in real time is essential. The benefits distribution strategy is expected to resolve some of the technology related and personal constraints expressed by 
the affected farmers on obtaining the benefits provided by the Government. The strategic action plans suggested in this regard are provided:

\section{Long term empowerment strategies}

As the name suggests, Long Term Empowerment Strategies will have stretched gestation period but the outcomes of these strategies are strong and sustained. Long term strategies involves high investment, resource intensive and capability building. The strategic framework developed in this regard includes levers like (a) Crisis Preparedness, (b) Production Capability and (c) Services and Policy.

\section{Crisis preparedness}

A crisis (from the Greek кpíoıs - krisis; plural: "crises"; adjectival form: "critical") is any event that is, or is expected to lead to, an unstable and dangerous situation affecting an individual, group, community, or whole society. It is easier to stop something happening in the first place than to repair the damage after it has happened.

A natural disaster of Thane's scale is bound to bring in crisis situation and more such disasters are expected in the study area as it is prone to disasters in the past. Hence, it is essential to focus the efforts on to preparing the communities well in advance to minimize or mitigate the impact envisioned.

The cycle of disaster management begins with Preparation. This is primarily due to the reason that a well prepared community can survive and sustain the impact of natural disasters to a better extent than a relatively unprepared community. The action elements suggested to prepare the Thane affected cashew growers for any anticipated crisis situation in future is provided underneath.

\section{Zone specific disaster prediction and alert system}

Prediction is the first step to preparation. Disaster prediction is currently available at a macro zone level featuring the estimates of intensity and impact on a larger geography whereas, it is not sufficient enough to take up micro zone specific preparations. Though alert was provided about the incidence of Thane storm in the study area, it was not zone specific to develop a comprehensive action plan for preparations well in advance. This particular strategy will aid in mitigating some of the psychological constraints expressed by the respondents. The action plans suggested under this strategy are given:

\section{Disaster risk mitigation structures}

Structures and Facilities are essential part of any Disaster Management Cycle. Preparations to mitigate natural disasters primarily comprises development of infrastructure for shelter, medical assistance, food reserves etc.

Development of these structures might take its own sweet time to get established but will be a souvenir for the future generations. Some of the practicable action plans under theses strategic levers are provided:

\section{Capacity building}

Capacity development is a conceptual approach to development that focuses on understanding the obstacles that inhibit people, governments, international organizations and non-governmental organizations from realizing their development goals while enhancing the abilities that will allow them to achieve measurable and sustainable results. Capacity building in other terms aims at empowering the Thane affected cashew growers with adequate knowledge, technical skills and competencies to take up disaster mitigation 
measures with less dependency on external sources.

While Training and Development aims at developing the knowledge, competencies and skills of the Thane affected cashew growers, Natural Resources Augmentation targets sustainability of existing natural resources like soil, water and biodiversity in Thane affected cashew growing region.

\section{Training and development}

Training is a process of structured transfer of knowledge, practice on skills and building competencies of individuals or groups. Continued training and practical utility of the skills \& competencies gained through training will result in development. The following are the suggested action points under the training \& development strategic lever.

\section{Natural resource augmentation}

Augmentation of existing natural resources will have a positive impact on the climate change scenario apart from strengthening the existing resource capability. It will also provide adequate stress handling capacity during disaster situations. Augmented natural resources will provide continued access to the farmers for healthy soil, water etc. to continue with farming. The detailed action points are provided:

The strategies and action plans discussed above can be tabled with relevant agencies for drawing location specific long term execution plans and implementing the same.

\section{Services and policy}

Access to Basic Services during disaster conditions would ease out significant efforts put in towards mitigation. Hence drawing exhaustive plans to have sustained supply chain and services network is critical for effective management of disasters. Future proofing policies are a must have factor with respect to the context of disaster management. Proactively sensing the needs of the future and securing those needs with favourable policy environment is essential for effective disaster management.

\section{Strengthening basic services}

Access to Basic Services is essential for leading a normal and healthy life. Basic services in this regard are food, potable water, sanitation, health, electricity, roads, transportation and telecommunications.

During the study in the Thane affected cashew growing region, majority of the affected growers reported that, access to basic services like food, transport, sanitation and telecommunications were worst hit during Thane storm. Some of the strategic recommendations were evolved during the study to enhance and strengthen the basic services of the disaster prone zone.

\section{Localised disaster management apex body}

At national level and state level, there are disaster management apex bodies established and they hold the responsibility of scientific management of disasters. The lead time and mobilization of resources are practically difficult due to the geographically dislocated operations. Like any banks, institutions etc. possessing localized offices; a micro zone level disaster management agency particularly in coastal areas shall be established to achieve timely and effective management of natural disasters. This in a way enables the developmental agencies to tailor or customize suggestions and solutions that are specific to the area of focus.

For a farmer, who is continuously being affected by natural disasters, incurring heavy losses year after year; it is indeed a dream to have a localized disaster management body to taking care of execution of all the disaster management interventions by eliminating conspicuous roles of multiple agencies. Hence a prescriptive model is developed cognizing to 
various revelations, understandings and importance of this study in empowering Thane affected cashew growers. As discussed above the model is rightfully named as "DREAMS"Disaster Risk Elimination and Management System. The proposed prescriptive model is given as follows in (Fig.3\&4).

The fundamental thing human beings have to understand is the fact that, "we have no control over nature". The only deed humans shall do to the nature is to respect it and not to manifest it in the name of growth or development. Nature has its own way. Sometimes it is soothing, sometimes it is ferocious. Man has always been threatened by the fury of nature from the very beginning of his existence on this earth. Sometimes disasters like earthquakes, cyclones etc., occur repeatedly with serious impact on all spheres of life. Be it earthquake in Gujarat in 2001 and Lattur in 1993 or cyclone of Orissa in 1999 or Tsunami in 2004 and Thane storm in 2011. It is alarming to understand that the disaster prone areas are being increasingly affected by intensification of the incidence of natural disasters. With technology and intelligence, humans can only predict the incidence of a natural disaster but are not capable to stop a disaster from happening. In this juncture, it is time for all the stakeholders of Agriculture, Horticulture, Animal Husbandry, Environmental Sciences, Policy Makers, Bureaucrats, NGOs etc., to join hands in developing advanced disaster management strategies involving precise prediction, effort worthy crisis preparedness, strategic action plans to mitigate the impact and large scale localized solutions to empower the farmers in the disaster prone zones of the country. The prescriptive model proposed in the study viz.,
"DREAMS"- Disaster Risk Elimination and Management Systemmay be adopted in order to empower the Thane affected cashew growers.

\section{References}

Chandramohan, 2006. Post Tsunami Agriculture Livelihood Restoration - a District Level Co-ordination Effort. Paper presented at the Workshop on Disaster Preparedness in Agriculture, National Coordination Resource Centre (NCRC), Nagapattinam District, Tamil Nadu.

Directorate of Horticulture and Plantation Crops, Agriculture Department and Government of Tamil Nadu, 2012. Cyclone Thane: http://tnhorticulture.tn.gov.in/horti/cyclon e-thane.

Krishnamoorthy, S. S., 2014. Policy Note: Demand No.5 - Agriculture 2014-2015. Government of Tamil Nadu.

Punithavathi, S. Tamilenthi and R. Baskaran, (2012).A Study of Thane Cyclone and its Impacts in Tamil Nadu, India using Geographic Information System.Archives of Applied Science Research, 4 (1): 685695.

Tamil Nadu Tsunami Resource Centre (TNTRC), 2006. Agricultural Rehabilitation Scenario in India: Paper presented at the Regional Workshop of Agriculture in Tsunami Affected Area: One and A Half years later Organized by FAO regional office for Asia and Pacific on 29-30, June 2006 at Bangkok, Thailand.

Women Federation, 2012. Rapid Assessment: Thane Cyclone Affected Villages in Cuddalore, Cuddalore.

\section{How to cite this article:}

Balarubini, M., C. Karthikeyan and Sujeetha, T.N. 2017. Empowerment of Disaster Affected Farmers - A Comprehensive Study on Developing Feasible Strategies for Empowering Thane Affected Cashew Growers in Cuddalore District of Tamil Nadu. Int.J.Curr.Microbiol.App.Sci. 6(11): 4001-4011. doi: https://doi.org/10.20546/ijcmas.2017.611.469 